\title{
Private Equity Funded Firms IPOs Short-term Performance Descriptive Analysis: Case of Casablanca Stock Exchange (CSE)
}

\author{
Sabrine BELQASMI \\ Research and studies Laboratory in Finance, Auditing and Management, National School of Commerce and \\ Management (NSCM), Tangier, Morocco \\ Abdelmalek Essaâdi University, Tetouan, Morocco
}

\begin{abstract}
:
The underpricing phenomenon has been well recognized in all the stock markets in the world. This study aims first to analyze the existence of underpricing issue of Moroccan IPOs, and then to measure this performance on a sample of 13 funded firms listed in Casablanca stock market from 2000 to 2018. The results show that the performance increases from $18,1 \%$ the $1^{\text {st }}$ day to reach $37 \%$ the $30^{\text {th }}$ day
\end{abstract}

Keywords: private equity, IPO, underpricing,

JEL Classification: G10, G11, G15, G20, G23, G24, G31, G32

DOI: $10.7176 /$ RJFA/12-4-06

Publication date: February $28^{\text {th }} 2021$

\section{Introduction}

Given the diversity of players, IPO operations are often carried out in a context of informational asymmetry which has direct consequences on the pricing of listed assets which often observe a discount or an underpricing. Often explained by an ex ante information differential between stakeholders on the real value of the assets issued, or as a signal from the issuers.

Overall, the review of the degree of underpricing analysis determines the existence of positive initial returns in all stock markets. The level of underpricing varies from country to country and depending on whether the market is developing or developed.

Likewise, the literature has also focused on the impact of investors on this performance of IPOs and their certifying effect by studying their role in the reduction of the level of informational asymmetry, and the reduction of conflicts agency and therefore in improving the performance of the IPO.

In this paper, we are interested in the short-term performance of IPOs of companies financed by private equity investors by measuring its evolution during the first 30 days after listing on a sample of 13 funded firms listed in the Moroccan market between 2000 and 2018.

The document will be organized as follows. first, we present a non-exhaustive literature relating to the study of the short-term stock market performance of companies listed on the stock exchange. then we describe the methodology adopted and the sample before closing with the results

\section{Literature Review}

One of the most widely studied phenomena in the finance literature is the return of the IPO (Initial Public Offerings) starting price, and it is in this context that a large number of Theoretical and empirical researches has been carried out in order to understand this phenomenon of underpricing. Thus, the first significant contributions in the performance of IPOs measured by underpricing were made by:

Reilly and Hatfield (1969), whose study involved a sample of 53 IPOs between December 1963 and June 1965 , and where they found a positive abnormal return of $9.9 \%$ on the first week of trading,

Stoll and Curley (1970), who analyzed the case of a sample of 643 small firms entered on the stock market in 1957, 1959 and 1963 as part of a special regulation (designed specifically for companies whose amount of issue was less than $\$ 300,000$, to enable them to present simplified financial information), the results achieved being a $42.4 \%$ return

McDonald and Fisher (1972) who studied the stock market behavior of newly-traded securities from a sample of 142 US companies introduced in the first quarter of 1969 , and the profitability of the sample averaged $28.5 \%$ for the first week, $34.6 \%$ for the second week, and $-3.2 \%$ for the third week.

Logue (1973), which considers that none of these two previous studies presented a rigorous attempt to explain this undervaluation according to the attributes of the program itself, contemporary market conditions, or the qualities of the parties. relevant models, ie the issuing company, the subscriber (or introducing banker), and the potential investor, whether estimates from a sample of 250 new IPOs including 2 sub-samples of programs made by "prestigious" and "non-prestigious" subscribers but that in all 250 issues, prices were set after negotiation of the parties concerned, and concludes that any explanation of the performance of new emissions must incorporate the implications of the monopsony model into its structure.

McDonald and Jacquillat (1974) when they study a sample of 31 IPOs carried out in France between 1968 
and 1971 , and note an average undervaluation of $3 \%$ on the first day, $4.8 \%$ the first week and $5 \%$ the first month.

However, Ibbotson (1975) is the first to provide an explanation for the phenomenon of underpricing by saying that issuers would like to "leave a good taste in investors 'mouths" ("leave a good taste in investors' mouth"). Anglo-Saxon expression) so that the next subscriptions solicited by these same issuers can be realized at a favorable price, in his study considered pioneering, on a sample of 128 IPOs carried out during the period 19601969 in the US, and in which he highlighted an initial profitability of $11.4 \%$,

Leland and Pyle (1977) propose in a theoretical model analyzing the fraction of shares held by the entrepreneur as a favorable signal of the growth opportunities of the company thus conveying information to future investors on the quality of the company., and thereby positively influencing the value of the security, resulting in a correct valuation of the value of the company

Jacquillat et al. (1978) affirm the existence of a positive average of abnormal returns after IPOs by measuring an undervaluation of $15 \%$ over the first six months of trading of a sample of 60 IPOs on the French market between 1966 and 1974.

Baron (1982) proposes, in his model, that the subscriber is more informed about the new issue market than the issuing company, as a result, and under the assumption that the issuing company is unable to control or measure the efforts provided. by the subscriber in the transaction, the latter is encouraged to undervalue in order to minimize its risk of selling the entire amount involved in the transaction, to potential investors

Titman and Trueman (1986) find a negative relationship between the presence of reputable auditors and the degree of undervaluation Carter and Manaster (1990) explain the underpricing by the presence of uninformed investors whose subscription is necessary for the success of the introduction operation.

Taking as basis the work of Leland and Pyle (1977), Titman and Trueman (1986), Carter and Manaster (1990) several authors such as Barry et al. (1990), Megginson and Weiss (1991), and Brav and Gompers (1997) manage to show a link between the presence of Capital Investors during the IPO and the level of underpricing by indicating that the degree of valuation depends on whether an IPO is backed by venture capital or not, and specifically show that backed IPOs are more severely underpriced than backed IPOs.

Thus, Barry et al. (1990) examining a comprehensive set of 433 IPOs of venture-backed companies and 1123 IPOs non-backed over the period 1978 to 1987 examine whether financial markets recognize the oversight and control provided by venture capitalists, and find that IPOs with higher quality VCs are less undervalued, leading them, by taking the empirical evidence as a whole, to assert that venture capitalists play an important role in governance and recovery newly created companies.

Similarly, Megginson and Weiss (1991) taking a sample of 320 venture-backed companies and 320 other non-backed firms operating in the same sectors and as close to each other in terms of size, floated on the stock market between January 1983 and September 1987, show that the IPOs of the companies supported score relatively poorly on the first day, which they attribute to venture capital certification which reduces the informational asymmetry between investors and investees

Jain and Kini (1995), based on the results of their previous study involving 682 listed IPOs between 1976 and 1988, (Jain and Kini (1994)), measure the operational performance of 136 IPOs supported and 136 non-capitalsupported IPOs. risk, and find better post-IPO operational performance.

Lin (1996), for its part, shows the role of shareholder certification in the IPO process, taking as an example a sample of 497 venture-backed IPOs and 2137 non-backed IPOs, and thus confirms the recognition by the market for the presence of venture capital in an issuing company through a reduction of underpricing of its assets during the IPO.

Brav and Gompers (1997), using a sample of 934 IPOs of US venture-backed firms during the period 19721992, and 3407 IPOs of non-backed firms during the period 1975-1992, find that they surpass the IPOs of nonbacked companies. This superior performance of the backed firms IPOs is often attributed to the establishment of management teams and better corporate governance structures that help these firms to achieve better long-term success.

Lin and Smith (1998) also looked at the performance of CI-sponsored IPOs by taking a sample of 2,634 US firms between 1979 and 1990 and found that venture-backed IPOs, and especially those that used better Subscribers with good reputations achieve a lower undervaluation because of this dual reputation: that of the venture capital company and that of the subscriber.

Hamao, Packer and Ritter (2000), using a sample of 355 IPOs of venture-backed Japanese firms between 1989 and 1994, find no evidence of long-term outperformance of venture-backed firm IPOs, except for companies backed by foreign venture capital firms or independent venture capitalists.

Hogan, Olson and Kish (2001) analyzing the first-day performance of LBOs and comparing them to original IPOs, show that if the original IPO had an original return of $13 \%$, LBO had an average yield surplus of $7.64 \%$, thus confirming the theory of informational asymmetry that undervaluation is significantly reduced when firms are supported by LBO.

Ray da Silva Rosa, Gerard Velayuthen, Terry Walter (2003) On a sample of 333 IPOs of industrial firms 
identified in Australia between 1991 and 1999 and 38 of which are backed by venture capital, find no statistically significant difference between IPOs and venture-backed

Lee and Wahal (2004) examine a sample of 6413 IPOs between 1980 and 2000, of which 2383 are venturebacked and show that the supported IPOs outperform the non backed IPOs by finding a trend. up over the entire period with a yield spread of between 5.0\% and 10.3\% over the period 1988-1998 and a much larger gap during the 1999-2000 internet bubble.

Hadryd, Mietzner and Shciereck (2010) have more closely studied under-valuation and long-term performance and have justified that they reflect the degree of information asymmetry between issuer and investor. Under the assumption that the level of undervaluation is a negative function of the reputation of the pimp, they try to distinguish between private equity and venture capital by the supported firms, which are smaller and high growth in the case risk capital, and have greater maturity in the case of private equity, to analyze whether a difference in undervaluation or long-term performance is observable, the study predicts that private equity firms low returns and low underpricing, and confirms that the level of underpricing is higher in the case of venture-backed companies than in private equity-backed ones.

Krishnan, Masulis, Ivanov, and Singh (2011) provide further support to Brav and Gompers (1997) 's point of view by confirming that better-performing venture capital firms invest in holding companies with better long-term performance. post-IPO term.

Levis (2011) studies a sample of 1,595 IPOs including those supported by venture capital and private equity during the period January 1992 to September 2005 at the London Stock Exchange, examining operational performance, and the result is that the companies supported decline a better performance than unsupported ones.

Ritter (2011) also demonstrates, in a study covering the period 1980-2006, an average adjusted return of $12.9 \%$ for IPOS supported by venture capital and an equivalent return of $7.1 \%$ for their counterparties in Private equity LBOs.

Chemmanur, Simonyan, Tehranian (2012) asserted that the quality of the venture capital management team plays a certification role in transmitting a company's intrinsic value to the market, thereby reducing information asymmetry. They assume that companies supported by private equity / venture capital are associated with a higher quality of management compared to companies not supported by private equity / risk capital.

Finally, although this review is not exhaustive, all of the authors quoted, and many others, have tested, in one way or another, the impact of private equity on company performance. By bringing together, then, the various studies concerning performance during and post-IPOs and especially those establishing the link between the active involvement of Capital Investors in the financed companies and its link with undervaluation, it appears ultimately in the literature that the presence of CIs at the time of IPO can have a positive impact on the level of undervaluation and in some cases on post-IP0 performance in the medium and long term.

\section{Methodology}

\subsection{Sample and data:}

The constitution of our sample is established on the basis of newly listed companies.

Among the 75 IPOs between the year 2000 and the year 2018, we eliminated, first of all, companies belonging to the financial sector (banks, insurance companies and finance companies, etc.), due to the fact that they are subject to precise regulations on accounting and prudential ratios.

Then, we selected the companies whose information on the identity and shareholding of shareholders in their capital before and after IPO is complete, and on the matching criteria that we have chosen.

In total, we obtained 26 companies, 13 of which are financed by Private Equity which constitute our basic sample, the 13 others form the control companies.

A matching methodology was used based on a three-fold criterion of market capitalization, company size and industry.

We then matched each of the 13 funded firms with the one that has the same criteria (within a range of + or $30 \%$ for capitalization)

\subsection{The dependent variable: Short-term performance (initial underpricing)}

Regarding the valuation state, for each IPO, researchers generally use the classic method which estimates the initial return to equilibrium according to two measures for underpricing, either with or without market adjustment:

- The underpricing, denoted RI i, t, which presents the unadjusted initial return, is calculated according to the following equation:

With:

$$
R_{i, t}=\frac{P_{i, t}-P_{i, 0}}{P_{i, 0}}
$$

- $\quad$ RI i, t: is the initial profitability for company "i" on day t after IPO;

- $\quad \mathrm{Pi}, 0$ : represents the subscription price for company “i”; 
- $\quad \mathrm{Pi}, \mathrm{t}$ : is the closing price on the th trading day $(\mathrm{t}=1,5,10,20$ and 30 trading days $)$ after company "i" has been listed on the stock market.

The sign of the relative spread between the equilibrium price and the offer price provides information on the valuation status of IPOs of the securities. The security is said to be undervalued if the difference is positive $(\mathrm{RI}>1)$ and overvalued by the market otherwise. $(\mathrm{RI}<1)$

- And the adjusted undervaluation, denoted RIA i, $t$, which presents the initial return adjusted to the movement of the market. To adjust these returns, we use the "MASI" index (Moroccan All Shares Index) which is a composition of all the securities listed on this market.

The initial underpricing in this case is measured by the initial profitability of the security "i" on day $t$ adjusted by the market return (MASI index) on the same day $t$, as explained in the equation below :

With:

$$
R_{i} A_{i, t}=\frac{P_{i, t}-P_{i, 0}}{P_{i, 0}}-\frac{M_{t}-M_{0}}{M_{0}}
$$

- $\quad$ RIA $\mathrm{i}, \mathrm{t}$ : is the initial profitability adjusted by the market return for company "i", on day $\mathrm{t}$ after IPO.

- $\quad \mathrm{Pi}, 0$ : represents the subscription price for company "i",

- $\mathrm{Pi}, \mathrm{t}$ : is the closing price on the $\mathrm{t}^{\text {th }}$ trading day $(\mathrm{t}=1,5,10,20$ and 30 trading days $)$ after the IPO of company "i",

- $\quad$ Mt: is the closing value of the market index on day $t$ after introduction of security "i",

- M0: represents the level of the market index the day before the listing of this same security on the stock market.

\section{Empirical Results: descriptive statistics of abnormal initial returns.}

To analyze the abnormal initial returns of companies financed by private equity introduced over a period of 30 days after listing, we first use the method of calculating returns in discrete time. Then, we adjust the initial yield of the security by the corresponding yield of the Moroccan All Shares Index (MASI) taking into account the market fluctuations between the day the offer price is set and the first day of listing.

In the tables below, we present the parametric and non-parametric tests of the abnormal initial profitability of private equity-financed companies.

Table 1: Initial Returns (IR)

\begin{tabular}{|c|c|c|c|c|c|c|}
\hline & $\mathbf{N}$ & $\begin{array}{c}\text { IR } \\
\mathbf{1}^{\mathrm{er}} \text { Day }\end{array}$ & $\begin{array}{c}\text { IR } \\
5^{\text {th }} \text { Day }\end{array}$ & $\begin{array}{c}\text { IR } \\
10^{\text {th }} \text { Day }\end{array}$ & $\begin{array}{c}\text { IR } \\
20^{\text {th }} \text { Day }\end{array}$ & \begin{tabular}{c}
\multicolumn{2}{c}{ IR } \\
$30^{\text {th }}$ Day \\
\end{tabular} \\
\hline Average & 13 & $0,171 * * *$ & $0,396 * * *$ & $0,426 * * *$ & $0,373 * * *$ & $0,409 * * *$ \\
\hline Student test & 13 & 3,797 & 4,007 & 3,344 & 3,127 & 3,060 \\
\hline Médian & 13 & $0,116^{* * *}$ & $0,455 * * *$ & $0,391 * *$ & $0,404 * *$ & $0,437 * *$ \\
\hline Wilcoxon rank test & 13 & 2,832 & 2,589 & 2,481 & 2,411 & 2,341 \\
\hline
\end{tabular}

Table 2: Adjusted Initial Returns (AIR)

\begin{tabular}{|c|c|c|c|c|c|c|}
\hline & $\mathbf{N}$ & $\begin{array}{c}\text { AIR } \\
1^{\text {st }} \text { Day }\end{array}$ & $\begin{array}{c}\text { AIR } \\
5^{\text {th }} \text { Day }\end{array}$ & $\begin{array}{c}\text { AIR } \\
10^{\text {th }} \text { Day }\end{array}$ & $\begin{array}{c}\text { AIR } \\
20^{\text {th }} \text { Day }\end{array}$ & $\begin{array}{c}\text { AIR } \\
3^{\text {th }} \text { Day }\end{array}$ \\
\hline Average & 13 & $0,181 * * *$ & $0,399 * * *$ & $0,430 * * *$ & $0,348 * * *$ & $0,370 * * *$ \\
\hline Student test & 13 & 3,689 & 4,148 & 3,567 & 3,074 & 3,009 \\
\hline Médian & 13 & $0,110 * * *$ & $0,504 * * *$ & $0,399 * * *$ & $0,375 * *$ & $0,396 * *$ \\
\hline Wilcoxon rank test & 13 & 2,830 & 2,551 & 2,551 & 2,341 & 2,341 \\
\hline
\end{tabular}

The descriptive statistics of initial abnormal return reveal that the firms studied have an average underpricing on the first day of listing, of $17.1 \%$. Taking into account market fluctuations, the underpricing reaches almost the same percentage with an average of $18.1 \%$. The two calculated means of underpricing are statistically significant at the $1 \%$ level.

On the other hand, if we continue to examine abnormal return over a longer period of time, the IPO price offers a larger initial discount from the post-IPO prices. 
Indeed, by using the closing price of the 5 th day of quotation, the initial profitability is $39.6 \%$ (that adjusted to market returns is $39.9 \%$ ). It increases continuously over the other trading days to reach $40.9 \%$ on the 30 th trading day (profitability adjusted to market returns is 37\%), the results of the Student test from the 1st trading day until 30th day are all significant at the $1 \%$ level.

According to the Wilcoxon test on a single sample, the results show an abnormal initial return on the first day of trading of $11.6 \%$, significant at the $1 \%$ level (that adjusted to market returns is $11 \%$ significant at the $1 \%$ level ).

It increases continuously until the 5 th day to reach a median profitability of $45.5 \%$, significant at the $1 \%$ level (that adjusted to market returns is $50.4 \%$, significant at the $1 \%$ level). If we continue to analyze the median abnormal profitability over a longer period, we find that profitability recovers to $43.7 \%$ on the 30 th day of trading (that adjusted to market returns is $39.6 \%$ significant at the $5 \%$ ).

Figure 1: Evolution of Initial Returns.

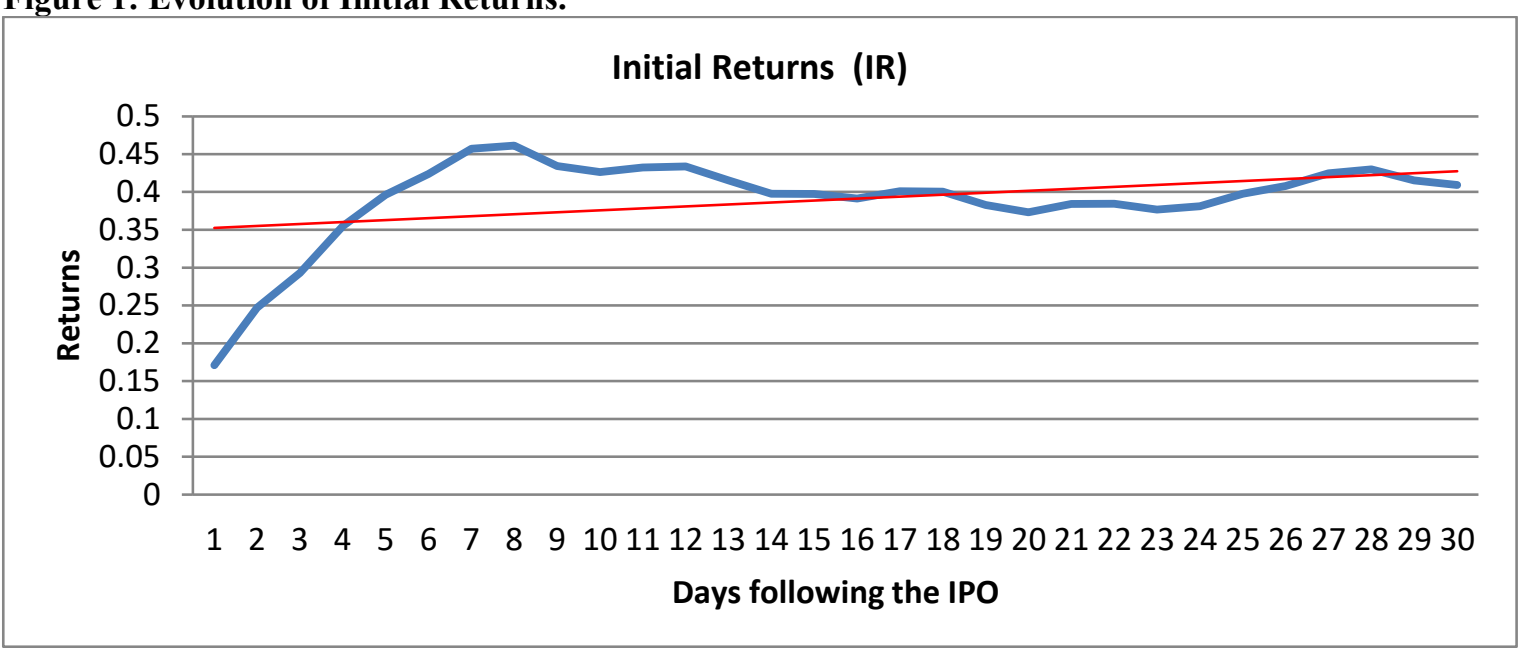

Figure 2: Evolution of Adjusted Initial Returns .

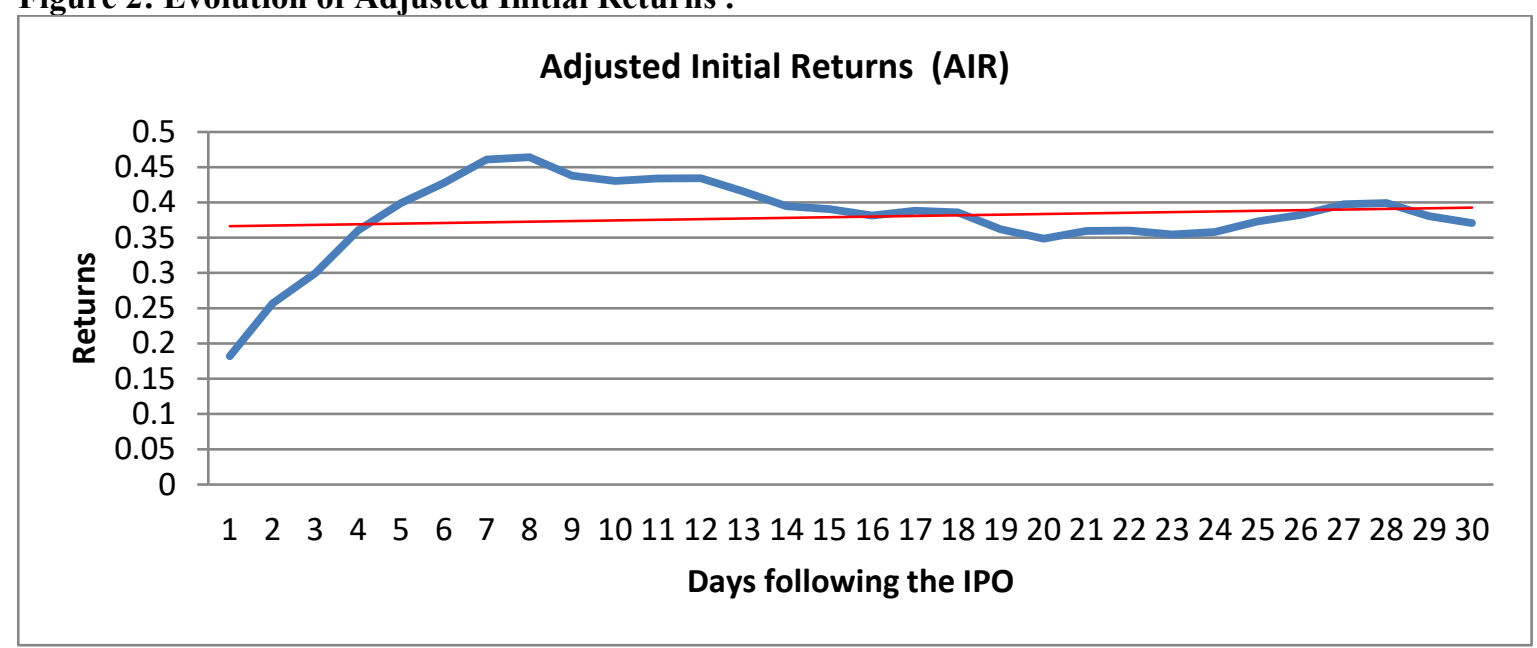

\section{Conclusion}

The present study aimed to analyze the IPO short-term performance within the context of the Casablanca Stock Exchange (CSE). This performance is measured first by the initial returns in the first $30^{\text {th }}$ trading days, then by initial returns adjusted to the Moroccan All Shared Indexes (MASI).

The results prove that underpricing increase from $17,1 \%$ on the $1^{\text {st }}$ day to $40.9 \%$ on the $30^{\text {th }}$ trading day, for initial returns (IR) and from $18,1 \%$ to $37 \%$ for adjusted initial returns (AIR).

To follow up on this research, it would be interesting to try to clarify in a subsequent research the different explanations given by the literature to this evolution of returns, and especially the impact of the involvement of capital investors in governance on short, medium and long term performance.

\section{References}

Baron D P. (1982). A Model of the Demand for Investment Banking Advising and Distribution Services for New 
Issues. The Journal of Finance, Vol. 37, $\mathrm{n}^{\circ}$. 4, pp. 955-976.

Barry C B. \& al (1990). The role of venture capital in the creation of public companies: Evidence from the going-public process. Journal of Financial Economics 77, 447-471. North-Holland

Brav A. \& Gompers P A. (1997). Myth or Reality? The Long-Run Underperformance of Initial Public Offerings: Evidence from Venture and Non venture Capital-Backed Companies. The Journal of Finance. Vol. LII, $n^{\circ} 5$.

Carter R. \& Manaster S. (1990). Initial public offerings and underwriter reputation. The Journal of Finance, Vol. 45, No. 4, pp. 1045-1067.

Da Silva Rosa R., Velayuthen G., Walter T. (2003). The sharemarket performance of Australian venture capitalbacked and non-venture capital-backed IPOs. Pacific-Basin Finance Journal, Vol $11 \mathrm{n}^{\circ}$ 2; pp. 197-218.

Daily C M. \& al. (2003). Corporate Governance: Decades of Dialogue and Data. The Academy of Management Review, Vol. 28, n 3, pp. 371-382

Hadrys C., Mietzner C., M., Schiereck,. M., D. (2010), Financial Sponsors, Underpricing, And Long-Run Performance: Venture Capital-Versus Private Equity-Backed IPOs, Journal of International Finance \& Economics, Vol. 10 n³, pp. 29-43.

Hamao Y., Paker F. and Ritter J., (2000). Institutional affiliation and the role of venture capital: Evidence from initial public offerings in Japan. Pacific-Basin Finance Journal, , vol. 8, issue 5, pp. 529-558.

Hogan K M., Olson G T. and Kish R J., (2001). A comparison of reverse leveraged buyouts and original initial public offers ; factors impacting their issuance in the IPO market. The Financial Review 8, pp. 1-18.

Ibbotson R G. (1975). Price performance of common stock new issues. Journal of Financial Economics 2, pp. $235-272$

Jacquillat B C. \& al. (1978). French auctions of common stock: New issues, 1966-1974. Journal of Banking and Finance 2, pp. 305-322.

Jain B A. \& Kini. O. (1995). Venture Capitalist Participation and the Post-Issue Operating Performance of IPO Firms. Managerial and Decision Economics, Vol. $16 \mathrm{n}^{\circ}$ 6. pp. 593-606;

Krishnan C N V, Ivanov V I, Masulis R W, and Singh A K. (2011). Venture Capital Reputation, Post-IPO Performance, and Corporate Governance. The Journal of Financial and Quantitative Analysis, Vol. 46, No. 5. 2011, pp. 1295-1333.

Lantz J-S. (1999). Les stratégies d'intermédiation financière en capital-investissement et l'évaluation de la firme lors d'introductions en bourse. thèse de doctorat, Université Aix-Marseille 3.

Lee P M. \& Wahal. S. (2004). Grandstanding, certification and the underpricing of venture capital backed IPOs. Journal of Financial Economics; Vol 73, pp.. 375-407.

Leland H E. \& Pyle D H. (1977). Informational asymmetries, Financial structure, and Financial intermediation. The Journal of Finance, Vol. 32, No. 2, pp. 371-387.

Levis. M. (2011). The Performance of Private Equity-Backed IPOs. Financial Management, Vol. 40, No. 1, pp. 253-277.

Lin T H. (1996). The Certification Role of Large Block Shareholders in Initial Public Offerings: The Case of Venture Capitalists. Quarterly Journal of Business and Economics, Vol. 35 n² 2, pp. 55-65.

Lin T H. \& Smith R L. (1998). Insider reputation and selling decisions: the unwinding of venture capital investments during equity IPOs. Journal of Corporate Finance, Volume 4, Issue 3, pp. 241-263;

Logue. D E. (1973). On the Pricing of Unseasoned Equity Issues: 1965-1969. The Journal of Financial and Quantitative Analysis, Vol. 8, n. 1, pp. 91-103.

McDonald J G. \& Fisher A. K. (1972). New-Issue Stock Price Behavior.The Journal of Finance, Vol. 27, No. 1, pp. 97-102.

McDonald J G. \& Jacquillat B C. (1974). Pricing of Initial Equity Issues: The French Sealed-Bid Auction. The Journal of Business. Vol. 47, No. 1, pp. 37-47.

Megginson W L. \& Weiss K A. (1991). Venture Capitalist Certification in Initial Public Offerings. The Journal of Finance, Vol. 46, No. 3, pp. 879-903.

Reilly F K. \& Hatfield K. . (1969). Investor Experience with New Stock Issues. Financial Analysts Journal, Vol. 25, No. 5, pp. 73-80

Ritter J R. (2011). Equilibrium in the IPO Market. Annual Review of Financial Economics, Vol. 3, pp. $347-374$.

Rock. K. (1986). Why new issues are underpriced. Journal of Financial Economics 15, 187-212. North-Holland.

Stoll H R. \& Curley. A J. (1970). Small Business and the New Issues Market for Equities. The Journal of Financial and Quantitative Analysis, Vol. 5, No. 3, pp.309 -322.

Titman S. \& Trueman B. (1986) «Information quality and the valuation new issues ». Journal of Accounting and Economics 8 , pp. 159-172.

Zouari S B S., Boudriga A. et N B. Taktak. (2011). Determinants of IPO underpricing: evidence from Tunisia. The International Journal of Business and Finance Research Vol. 5, Number 1. 